\title{
Фотолюминесценция SiSnGe гетероструктур
}

\author{
В.А. Володин ${ }^{1,2)}$, В.А. Тимофеев ${ }^{1)}$, М.П. Синюков ${ }^{1)}$, А.И. Никифоров ${ }^{1)}$ \\ ${ }^{1}$ Институт физики полупроводников им. А.В. Ржанова СО РАН, \\ Новосибирск, 630090, пр. Ак. Лаврентьева, 13 \\ ${ }^{2}$ Новосибирский государственный университет, Новосибирск, 630090, ул. Пирогова, 2 \\ тел:+7 (383) 333-2470, факс:+7 (383) 333-2771, эл.nочта: volodin@isp.nsc.ru
}

DOI 10.34077/RCSP2019-75

Интерес к твёрдым растворам $\mathrm{SiGeSn}$ связан с тем, что управляя составом можно управлять их зонной структурой, и есть предположения, что в таких твёрдых растворах можно достичь прямозонной структуры и получить эффективные излучатели инфракрасного (ИК) диапазона [1].

Гетероструктуры $\mathrm{Si} / \mathrm{Si}_{(1-\mathrm{x})} \mathrm{Sn}_{\mathrm{x}}$ и твёрдые растворы $\mathrm{SiGeSn}$ были выращены на подложке $\mathrm{Si}(001)$ в условиях сверхвысокого вакуума $10^{-7}-10^{-8}$ Па на установке молекулярно-лучевой эпитаксии "Катунь C”. Сначала осуществлялся рост буферного слоя кремния толщиной 150 нм при температуре $700^{\circ} \mathrm{C}$, затем происходил рост гетероструктур. Состав слоёв и толщины слоёв в гетероструктурах варьировались, содержание олова в твёрдых растворах $\mathrm{SiSn}$ варьировалось от 10\% (образец 1) до 25\% (образец 2, см. рисунок).

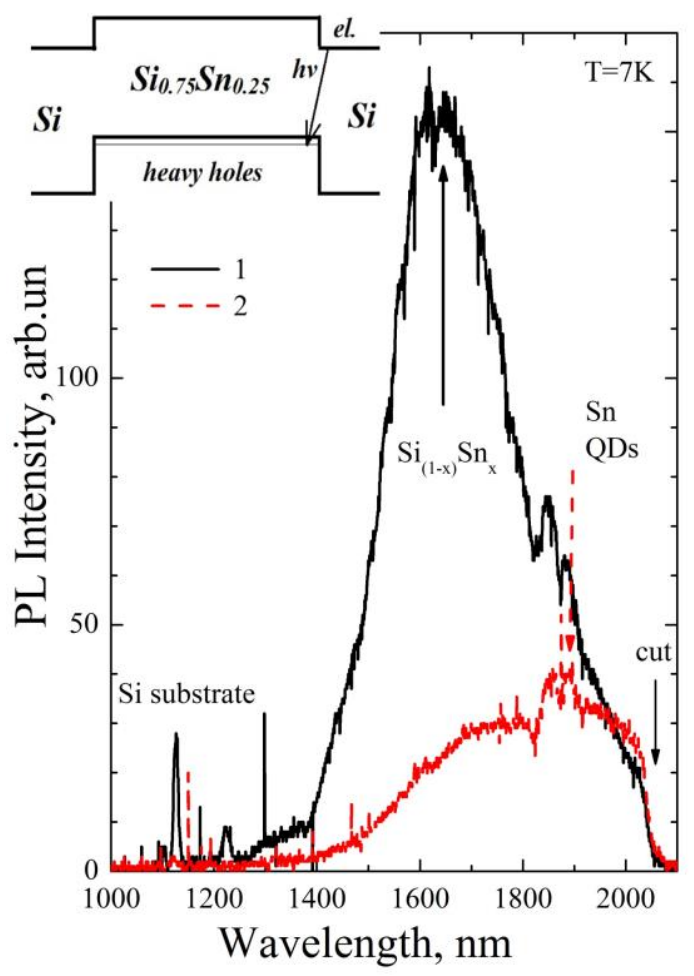

Многослойные гетероструктуры $\mathrm{Si} / \mathrm{Si}_{(1-x)} \mathrm{Sn}_{\mathrm{x}}$ а также твёрдые растворы $\mathrm{SiSnGe}$ были исследованы с применением спектроскопии комбинационного рассеяния света и фотолюминесценции. В спектрах комбинационного рассеяния света гетероструктур $\mathrm{Si} / \mathrm{Si}_{(1-\mathrm{x})} \mathrm{Sn}_{\mathrm{x}}$ обнаружены пики, соответствующие колебаниям связей $\mathrm{Si}-\mathrm{Sn}$, а также $\mathrm{Sn}-\mathrm{Sn}$, последнее позволяет предположить, что в гетероструктурах присутствуют нанокристаллы олова. В спектрах твёрдых растворов SiGeSn были обнаружены пики, соответствующие колебаниям связей $\mathrm{Sn}-\mathrm{Sn}, \mathrm{Si}-\mathrm{Sn}, \mathrm{Ge}-\mathrm{Si}$, и $\mathrm{Ge}-\mathrm{Sn}$.

Спектры фотолюминесценции измеряли с использованием мультиканального детектора на основе матрицы InGaAs-диодов. Длинноволновый край порога чувствительности составлял 2100 нм, корректировки спектров на чувствительность детектора не проводилось. При низких температурах в гетероструктурах $\mathrm{Si} / \mathrm{Si}_{(1-\mathrm{x})} \mathrm{Sn}_{\mathrm{x}}$ наблюдались две полосы фотолюминесценции - 0.75 эВ (1650 нм) и 0.65 эВ (1900 нм), первую можно связать с оптическими переходами в квантовых ямах в гетероструктуре второго рода $\mathrm{Si} / \mathrm{Si}_{(1-}$ х) $\mathrm{Sn}_{\mathrm{x}}$, а вторую с экситонами, локализованными в нанокристаллах олова (см. рисунок). В твёрдых растворах $\mathrm{SiGeSn}$ также была обнаружена фотолюминесценция в ИК диапазоне при низких температурах.

Авторы благодарны В.И. Машанову за помощь при росте образцов. Работа выполнена: в части роста образцов при поддержке РФФИ, гранты № 16-32-60005 - мол_а_дк, 18-42-540018 p_a, 16-2903292 офи_м; в части исследования методом спектроскопии комбинационного рассеяния света и фотолюминесценции по государственному заданию - Программа фундаментальных исследований ИФП СО РАН № 0306-2016-0015. В.А. Володин благодарен M.Vergnat и M.Stoffel (Université de Lorraine) за помощь в регистрации спектров фотолюминесценции.

\section{Лumepamypa}

[1] S. Wirths, R. Geiger, N. von den Driesch et. al., // Nature Photonics. 2015. V.9. P. 88-93.

[2] В.А.Володин и др. // Письма в ЖЭТФ. 2019. Т.109, вып.6. С.235-239. 